\title{
Delineation of Geothermal Manifestation in Sangubanyu Area Based on Microtremor HVSR Method
}

\author{
Dwi Sudarmawan Sudjono ${ }^{1, *}$, Udi Harmoko ${ }^{1,2}$, Gatot Yuliyanto ${ }^{1,2}$ \\ ${ }^{1}$ Master Program of Energy, School of Postgraduate Studies, Diponegoro University, Semarang, Indonesia \\ ${ }^{2}$ Department of Physics, Faculty of Science and Mathematics, Diponegoro University, Semarang, Indonesia
}

\begin{abstract}
The aims of this study is to describe the distribution of $\mathrm{P}$ wave velocity and $\mathrm{S}$ wave velocity value and $\mathrm{Vp} / \mathrm{Vs}$ ratio based on microtremor HVSR method and its relationship with the appearance of hot spring at Sangubanyu Village. Geothermal manifestations in the Sangubanyu area are located in Bawang sub-district, Batang regency, and Plantungan sub-district, Kendal regency, Central Java province. HVSR method is used to process microtremor data which produces the dominant frequency value and amplification factor then do inversion on the H/V curve to get the value of the $\mathrm{Vp}$ and $\mathrm{Vs}$. The results of the microtremor HVSR processing obtained the distribution of the dominant frequency values in the study area between 0.62 to $0.73 \mathrm{~Hz}$ and amplification factor values 1.09 to 1.39 , the inversion results on the $\mathrm{H} / \mathrm{V}$ curve obtained the distribution of $\mathrm{Vp}$ values between $131.76 \mathrm{~m} / \mathrm{s}$ to $2181.19 \mathrm{~m} / \mathrm{s}$, Vs values between 76.61 to $1129.42 \mathrm{~m} / \mathrm{s}$, $\mathrm{Vp} / \mathrm{Vs}$ ratio $1.64-3.35$. Based on the results of the analysis and wave velocity interpretation, the subsurface structure of manifestation area of Sangubanyu is composed of tuffaceous sandstone and volcanic breccia, the normal faults with southern blocks relatively downthrown, that cause the appearance of hot springs.
\end{abstract}

Keyword: microtremor; HVSR; geothermal manifestation; sangubanyu; Vp/Vs

\section{Introduction}

Geothermal energy is renewable and sustainable energy, environmentally friendly compared to fossil energy resources. Geothermal energy can be utilized directly and indirectly, for example, direct use is for tourism activities, agribusiness, industry, and other activities that use geothermal energy for direct use, while indirect use is for electricity generation, depending on the amount of temperature contained. Indonesia has a huge of geothermal potential in the world which is $29.4 \mathrm{GWe}$ equivalents to $40 \%$ of the world's geothermal potential but its utilization is still very small, less than $5 \%$ of the total potential [1]. Subsurface heat source is often indicated by surface manifestations, such as hot springs, mud pools, geysers, and other geothermal manifestations. Geothermal manifestations on the surface are estimated to occur due to the propagation of heat from the subsurface or caused by fractures that allow geothermal fluid (steam and hot water) to flow to the surface [2]. Therefore research on geothermal manifestations is very important.

The location of Sangubanyu geothermal manifestations is in the north of the Geothermal Working Area of the Dieng Plateau. Administratively it is in Sangubanyu Village, Bawang District, Batang Regency, and Tirtomulyo Village, Plantungan District, Kendal Regency, Central Java Province, geographically the study location is at coordinates UTM Zone 49S 385200-
$385800 \mathrm{mE}$ and $9214700-9215600 \mathrm{mN}$, elevation ranges between $629-720 \mathrm{~m}$ a.s.l. (Fig.1). The manifestation of the Sangubanyu hot spring has a temperature of $43^{\circ} \mathrm{C}, \mathrm{pH}$ 6.8 with chloride content 1400-2000 mg/liter [3], based on the numerical modeling results of steady conditions the subsurface temperature distribution The Sangubanyu geothermal manifestation area is an outflow zone of the Dieng geothermal system [4]. There has not been much research on subsurface structures in this area of manifestation.

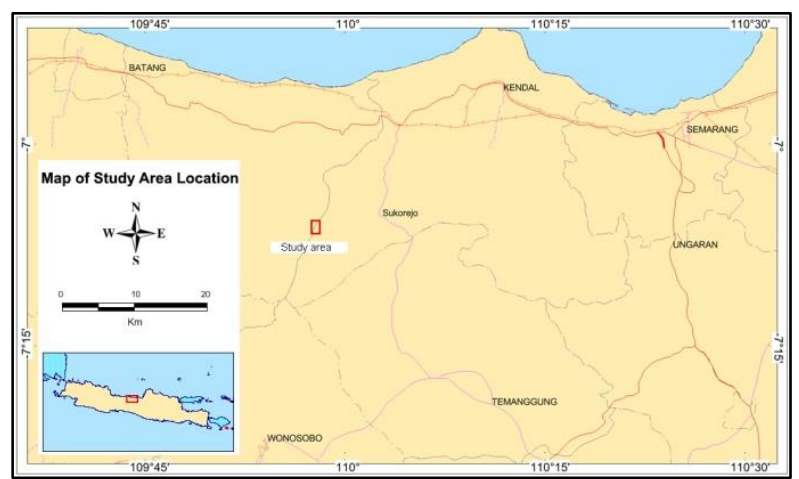

Fig. 1. Map of the study area location.

Microseismic can be used in geothermal exploration [5], the microtremor method is a passive seismic method for recording constant vibrations of the Earth's surface,

\footnotetext{
* Corresponding author: dwissst@gmail.com
} 
microtremors can be originating from daily human activities and natural phenomena [6], microtremors is also referred to as ambient noise, the vibration of the ground with a certain amplitude and can describe the geological condition of the region, an inverse analysis of microtremor $\mathrm{H} / \mathrm{V}$ data is presented for estimating shallow $\mathrm{S}$ wave velocity profiles of subsurface soils [7]. The aims of this study are to describe the distribution of $\mathrm{P}$ wave velocity $(\mathrm{Vp})$ and $\mathrm{S}$ wave velocity $(\mathrm{Vs})$ value and $\mathrm{Vp} / \mathrm{Vs}$ ratio based on microtremor HVSR method and its relationship with the appearance of hot spring at Sangubanyu Village so that recommendations for utilization can be determined.

\section{Geological Setting}

The Indonesian archipelago is a tectonic region in a geological complex that is influenced by the interaction of the Eurasian convergent plate in the north, the IndoAustralian plate in the south which moves relatively to north, and the Pacific plate in the east which moves relatively to west. Based on Physiography Map of Java and Madura [8] the study area is located in North Serayu Mountainous Zone, which is a Quaternary volcanic zone (Figure 2.)

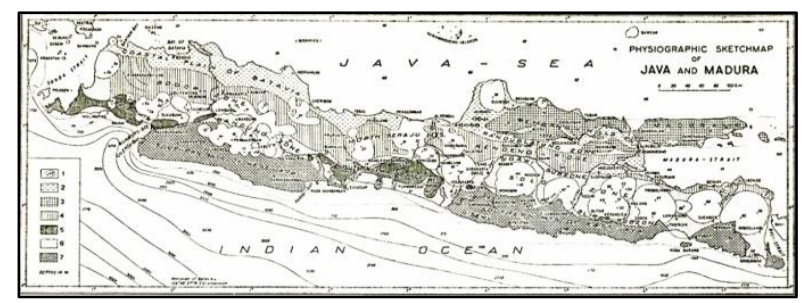

Fig. 2. Physiography Map of Java and Madura [8].

According to Geological Map of the Banjarnegara and Pekalongan [9] (Figure 3) the study area is composed of Alluvial Fan (Qf): mainly volcanic debris; dissected, and Kaligetas Formation (Qpkg): Volcanic breccia, lava flows, tuff, tuffaceous sandstone, and claystone. Flow breccia and lahar with intercalation of fine-to coarsegrained tuff. Locally mollusk-bearing claystone and sandstone occur at the lower part. Weathered volcanic are reddish-brown and often form big blocks. Thickness ranges from $50-200 \mathrm{~m}$.

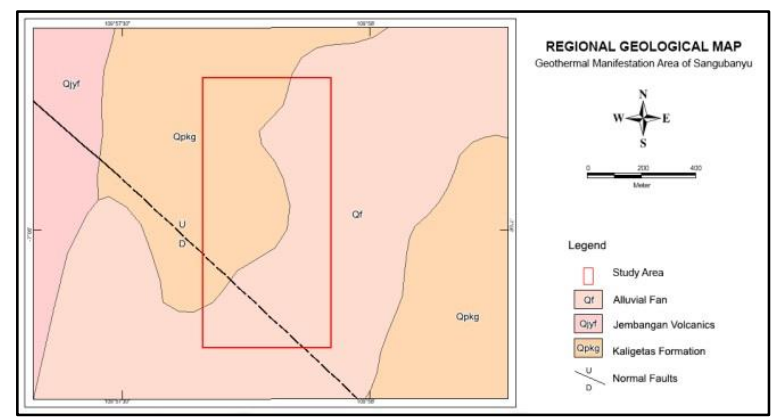

Fig. 3. Geological Map (Modified from [9]).
The geological structure is shown by lineament of dipslip fault where the southern block is relatively downthrown.

\section{Methodology}

Single station microtremor measurements of 17 points used Dataq Instruments DI-710 seismometer were carried out of Sangubanyu area by distances each point are between $160 \mathrm{~m}$ to $200 \mathrm{~m}$ (Figure 4), measurement duration is 15 minutes in each point and $300 \mathrm{~Hz}$ sampling frequency. Processing data from microtremor measurements using HVSR method by Geopsy software. HVSR method is based on a comparison between the spectral amplitude of horizontal components against vertical components [10]. The spectral ratio between horizontal components and vertical components is calculated by the formula:

$$
H / V(f)=\frac{\sqrt{\left.A_{\text {east }}(f)\right|^{2}+\left.A_{\text {north }}(f)\right|^{2}}}{A_{\text {vertical }}(f)}
$$

where $A_{\text {east }}(f), A_{\text {north }}(f)$ and $A_{\text {vertical }}(f)$ respectively are the spectral amplitudes of the east-west, north-south and vertical component. The important parameters generated from the HVSR method are the dominant frequency and soil amplification which are the peak values of the HVSR curve, related to the local geology and subsurface physical parameters [11].

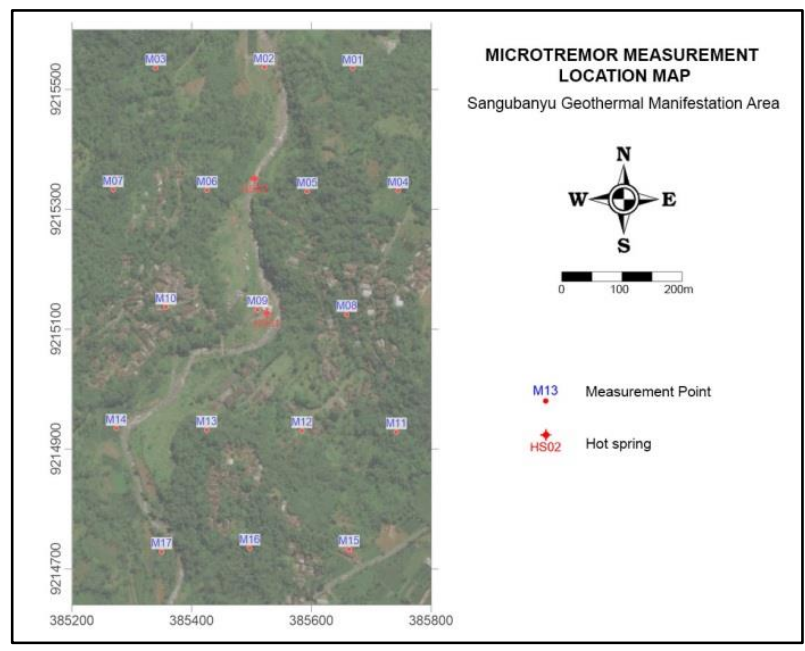

Fig. 4. Microtremor measurement location map.

Computation process on Geopsy, the window length for each data was set to 20 seconds, a sampling rate of 100 samples per second, process smoothing by Konno \& Ohmachi with smoothing constant value 40 and 5\% cosine taper value, the result of the process will be obtained an $\mathrm{H} / \mathrm{V}$ curve that characterizes the dominant frequency $\left(\mathrm{f}_{0}\right)$ and amplification factor $\left(\mathrm{A}_{0}\right)$ value. Next step, inversion process was carried out using the ellipticity curve method on the dinver software by entering the $\mathrm{H} / \mathrm{V}$ curve, which produces a ground profile of $\mathrm{Vp}, \mathrm{Vs}$, and density. 


\section{Result and Analysis}

The HVSR process in Geopsy produces a H/V curve as shown in Figure 5, based on the results of microtremor HVSR processing, it is known that the distribution of the dominant frequency values (Figure 6) in the manifestation area is between 0.62 to $0.73 \mathrm{~Hz}$ and the amplification factor value is 1.09 to 1.39 (Figure 7). There is no contrast difference in the distribution of frequency values or amplification factor values and there is no correlation between them. References [11] explained that the frequency value is inversely proportional to the thickness of the sediment or the depth of the bedrock, the amplification value is directly proportional to the impedance contrast between the sediment and the bedrock, these reflect the surface soil of the study area is composed by homogeneous soil characteristic and bedrocks depth. According to distribution map of $f_{0}$ value, hot springs are located on difference, not significant frequency value, HS-01 is $0.72 \mathrm{~Hz}$ and HS-02 is $0.64 \mathrm{~Hz}$, while the distribution of amplification factor values is 1.16 to 1.28 .

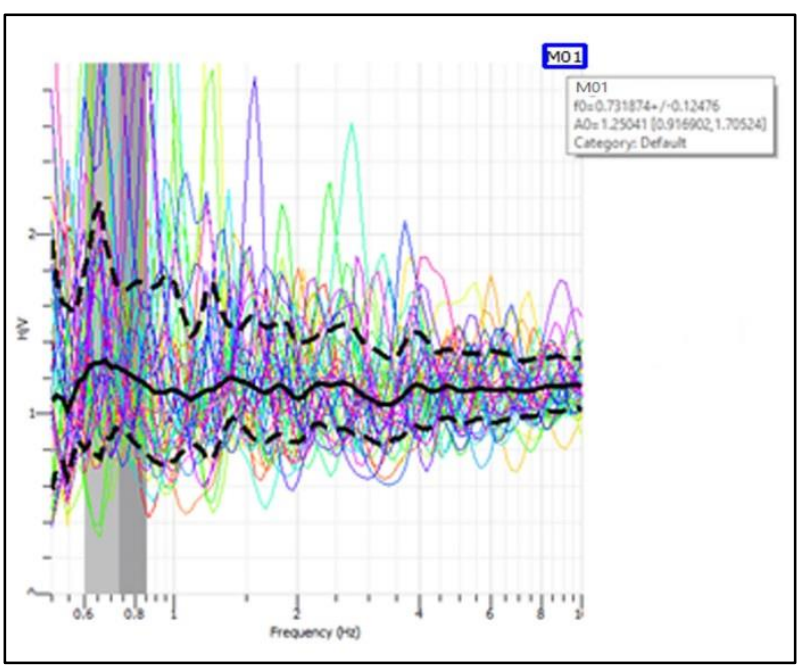

Fig. 5. H/V curve of site M01.

Figure 8 shows the results of inversion $\mathrm{H} / \mathrm{V}$ peak onsite $\mathrm{M} 09, \mathrm{H} / \mathrm{V}$ curve inversion performed on Dinver software produces profiling of $\mathrm{Vp}, \mathrm{Vs}$ and density values. Based on the results of the $\mathrm{H} / \mathrm{V}$ curve inversion at 17 measurement points obtained a range of $\mathrm{Vp}$ values ranging from $131.76 \mathrm{~m} / \mathrm{s}$ to $2181.19 \mathrm{~m} / \mathrm{s}$, the value of $\mathrm{Vs}$ between $76.61 \mathrm{~m} / \mathrm{s}$ to $1129.42 \mathrm{~m} / \mathrm{s}$ and the $\mathrm{Vp} / \mathrm{Vs}$ values in the study area ranged from $1.64-3.35$. Cross-section A-A' is drawn based on the closure of frequency values from south to north through the hot springs are shown in Figure 9. The distribution pattern of $\mathrm{Vp}$ and Vs values is relatively identical, the value is increasing as depth, there are striking differences values on the southern and northern parts. The distribution of $\mathrm{Vp} / \mathrm{Vs}$ values that pass through hot springs is $1.8, \mathrm{Vp} / \mathrm{Vs}$ values illustrate the elasticity properties of rocks [12] and correlated with pore fluid pressure [13]. according to the result of [13] that the combination of high $\mathrm{Vp}$, low $\mathrm{Vs}$, and high $\mathrm{Vp} / \mathrm{Vs}$ can be interpreted as rock fluid-saturated, in this study the combination is shown below HS-02, it reflects the potential area.

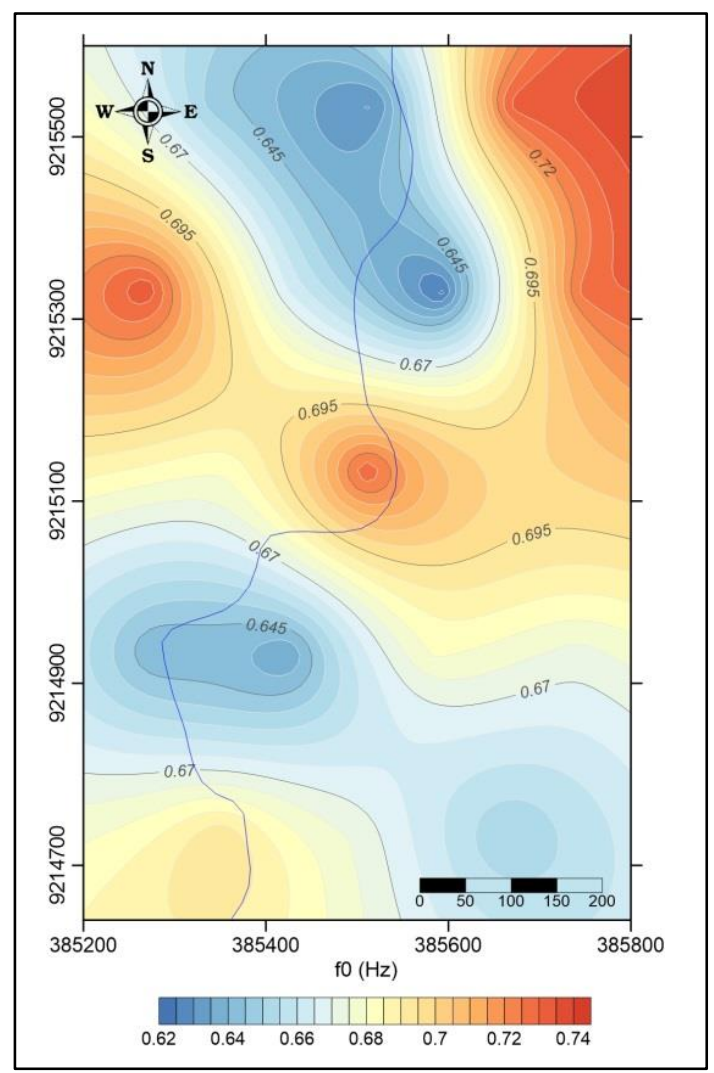

Fig. 6. Distribution of dominant frequency ( $\left.f_{0}\right)$.

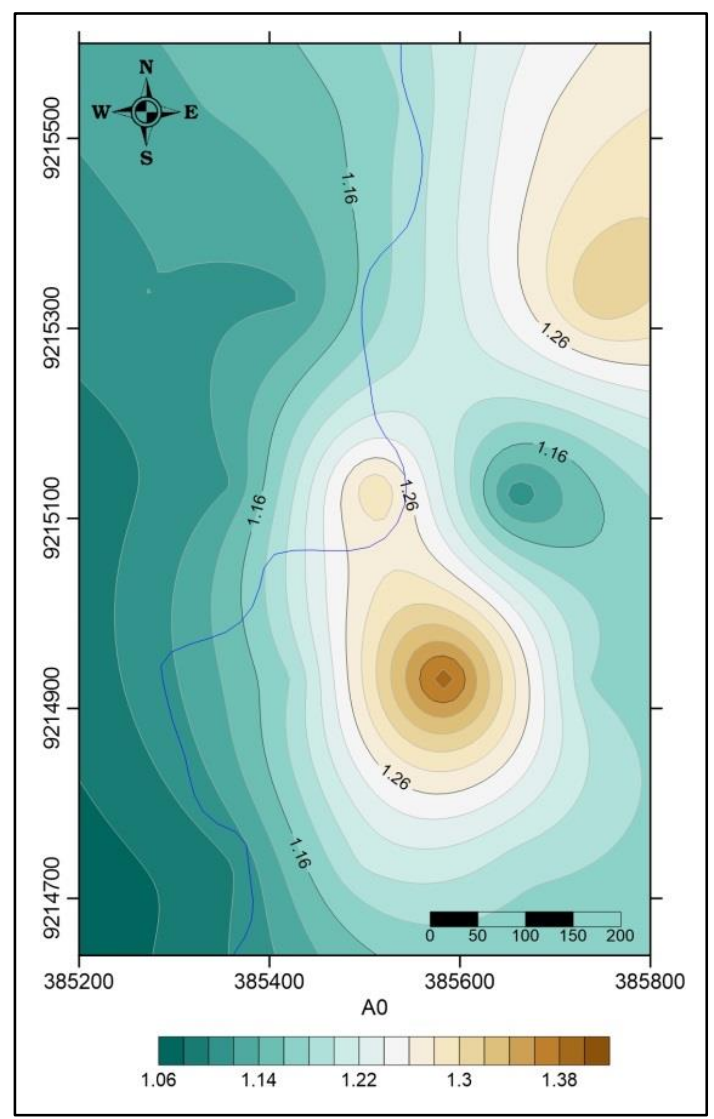

Fig. 7. Distribution of amplification factor $\left(\mathrm{A}_{0}\right)$. 


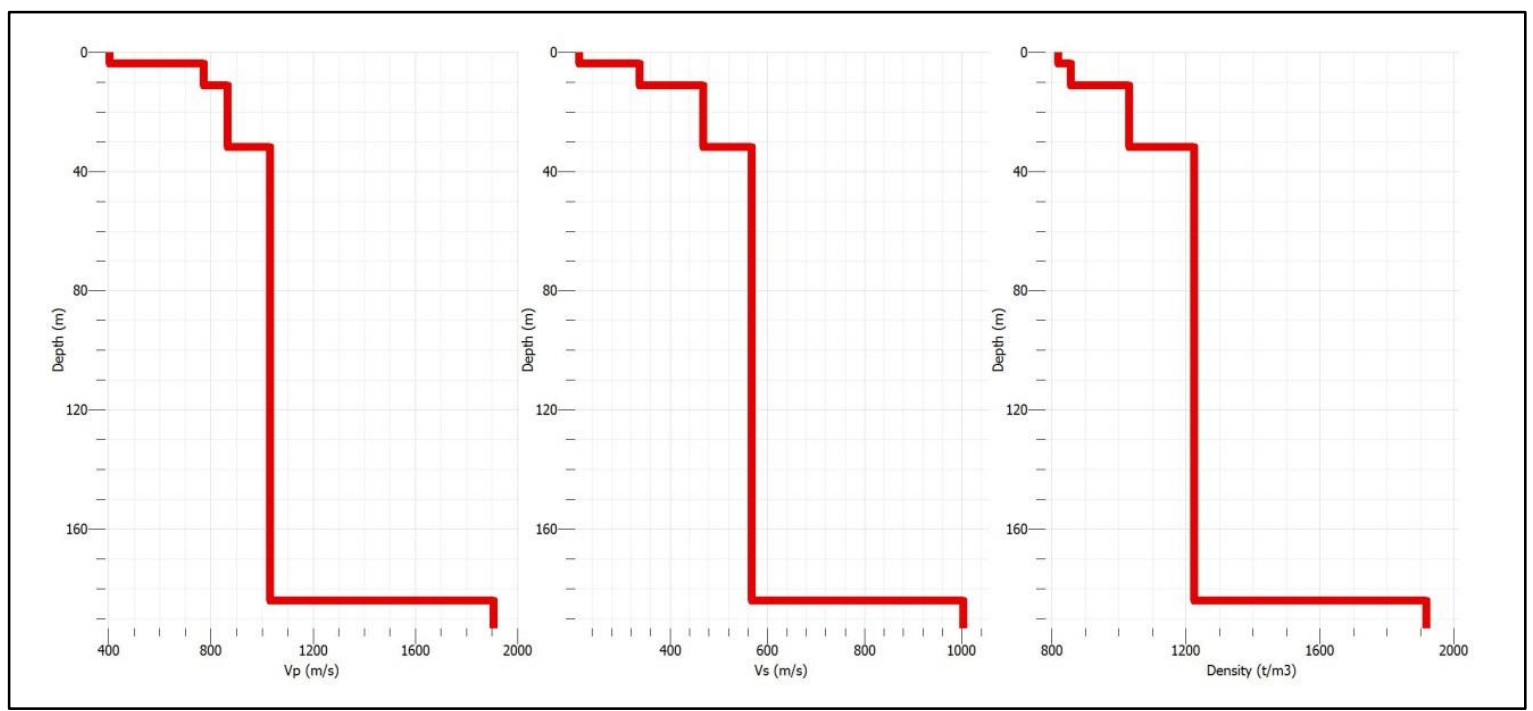

Fig. 8. Ground profile on site M09.

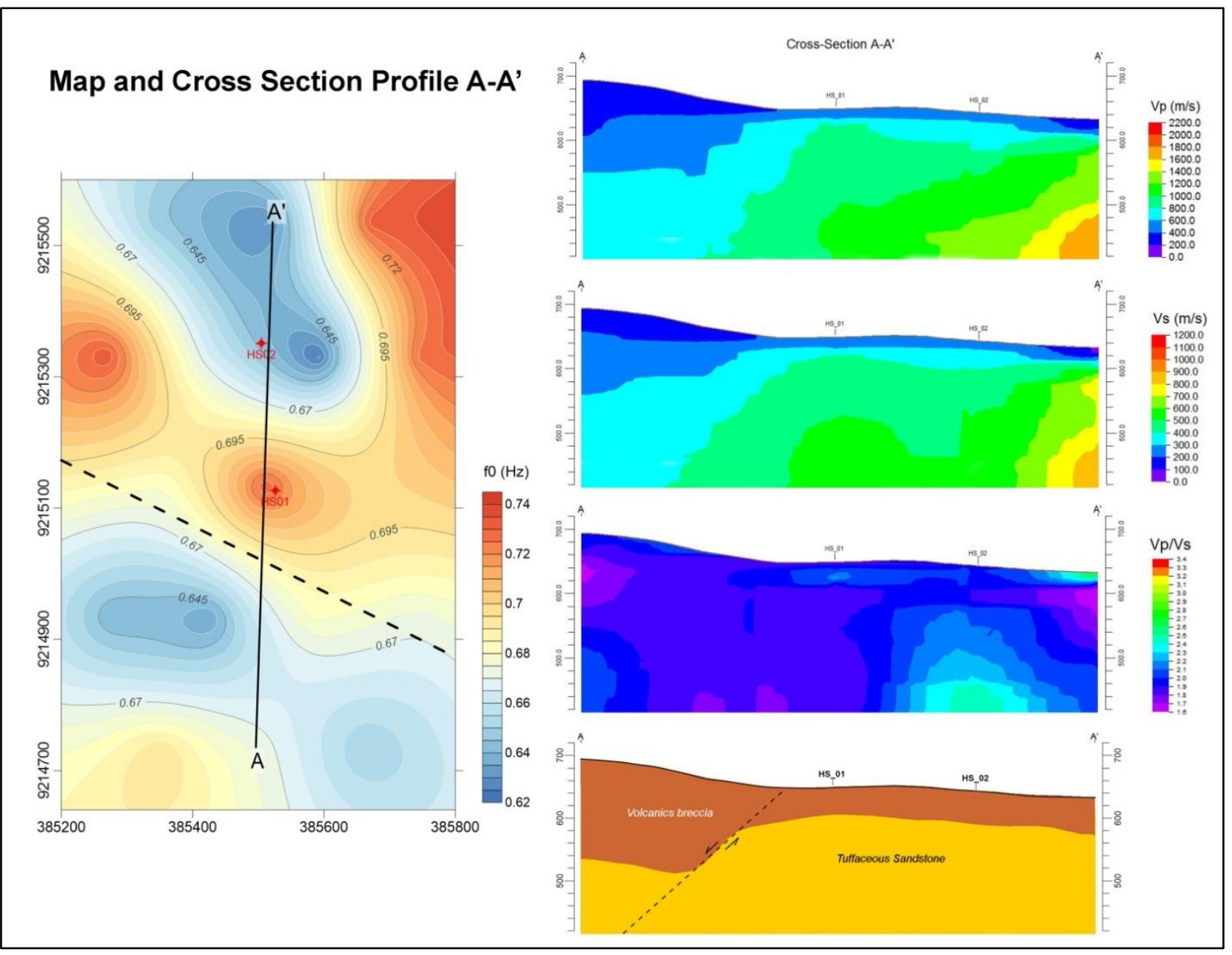

Fig. 9. Cross-section A-A', according to closure of distribution fo value. Showing variation on distribution of $\mathrm{Vp}, \mathrm{Vs}$, and $\mathrm{Vp} / \mathrm{Vs}$, and lithology models are determined based on the interpretation of wave velocity values.

Subsurface lithology is determined based on the interpretation of the distribution of wave velocity values then compared to outcrops in the field. Accordingly, the study area is composed of tuffaceous sandstone and volcanic breccia which can be compared with Kaligetas Formation [9].

\section{Conclusion}

The HVSR method can be used to determine the subsurface structure in the geothermal manifestation area. Based on the analysis of subsurface structures, it was identified the possibility of a normal fault with trend 
direction is northwest-southeast. The Sangubanyu geothermal manifestation area is in a weak zone. Hot springs appear on the surface caused by the presence of normal faults as heat propagation pathways. Geothermal energy produced can be used for bathing and drying agricultural products but needs further feasibility studies.

\section{References}

1. Pusat Data dan Teknologi Informasi ESDM. Kajian Penyediaan Dan Pemanfaatan Migas, Batubara, EBT dan Listrik (2017)

2. N. Mirjani Saptadji, Teknik Panasbumi (2002)

3. A. H. Truesdell, Geochemical Evaluation of The Dieng Mountains, Central Java, For The Production of Geothermal Energy (1971)

4. M. Noer Ali, U. Harmoko, G. Yuliyanto, T. Yulianto, Model of Temperature Distribution Geothermal Pesanggrahan Geothermal System, Central Java, Indonesia, IJRTER, 04 (2018)

5. D.D.B. Crosby' and I.B. Calman, Seismic Techniques In Geothermal Areas, Proceedings $18^{\text {th }}$ NZ Geothermal Workshop (1996)

6. H. Okada, The Microtremor Survey Method, SEG (2003)

7. H. Arai, K. Tokimatsu, S-Wave Velocity Profiling by Inversion of Microtremor $H / V$ Spectrum, Bulletin of the Seismological Society of America, 94, 53-63 (2004)

8. R. W. Van Bemmelen, Geology of Indonesia, 1A (1949)

9. W. H. Condon, L. Pardyanto, K. B. Ketner, T. C. Amin, S. Gafoer, H. Samodra. Peta Geologi Lembar Banjarnegara dan Pekalongan, Jawa (1996)

10. Y. Nakamura. A method for dynamic characteristics estimation of subsurface using microtremor on the ground surface. Quarterly Report of the RTRI (1989)

11. Sungkono, B. J. Santosa, Karakterisasi kurva horizontal-to-vertical spectral ratio: Kajian Literatur Dan Permodelan. Jurnal Neutrino, 4(1), 1-15. (2011)

12. W. Raharjo, I. R. Palupi, S. W. Nurdian, W. S. Giamboro, J. Soesilo, J. Phys.: Conf. Ser. 776 012114 (2016)

13. A. D. Nugraha, A. Syahputra, R. Sule, S. Widiyantoro, SEGJ Int. Symp. 11 (2013) 